\title{
Edgar Allan Poe e o Mare Tenebrarum
}

\author{
Cleber Vinicius do Amaral Felipe ${ }^{1 *}$ \\ ${ }^{1}$ Universidade Federal de Uberlândia, Uberlândia/MG - Brasil
}

\section{RESUMO}

A tempestade ocupou lugar de destaque nos contos de Edgar Allan Poe, especialmente por se tratar de um fenômeno conveniente à produção de um locus horrendus, um lugar tenebroso por meio do qual seria possível despertar em seus leitores os efeitos pretendidos. No entanto, antes do movimento romântico do século XIX, o incidente marítimo, enquanto tópica, mostrou-se recorrente em diferentes gêneros retórico-poéticos, especialmente nos exemplares épicos. Pretende-se, nesse artigo, mapear algumas descriçóes de tempestades para, em seguida, termos condiçôes de analisar a maneira como Poe imitou essa tradição para a elaboração de um conto em particular, intitulado "Manuscrito encontrado em uma garrafa" ("Manuscript found in a bottle"), publicado em 1833.

Palavras-chave: Edgar Allan Poe; tempestade; sublime; epopeia; locus horrendus.

\section{Edgar Allan Poe and the Mare Tenebrarum}

\begin{abstract}
Storms occupied a prominent place in the tales of Edgar Allan Poe because they were a convenient phenomena to produce a locus horrendus, a dark place through which it would be possible to arouse intended effects. However, before the Romantic movement, the maritime incident, as topos, was recurrent in different poetic genres, especially in the epic poems. This article aims to map some descriptions of storms so that it might be possible to analyze the way Poe imitated this tradition for the elaboration of a tale titled Manuscript Found in a Bottle, published in 1833.
\end{abstract}

Keywords: Edgar Allan Poe; storm; sublime; epic; locus horrendus.

DOI: http://dx.doi.org/10.1590/2237-101X02104308.

Artigo recebido em 4 de fevereiro de 2019 e aceito para publicação em 4 de maio de 2019.

* Professor da Universidade Federal de Uberlândia / Departamento de História, Uberlândia/MG - Brasil.

E-mail: cleber.ufu@gmail.com. ORCID: https://orcid.org/0000-0002-3930-3936. 


\section{Edgar Allan Poe y el Mare Tenebrarum}

\section{RESUMEN}

La tempestad ocupó lugar de destaque en los cuentos de Edgar Allan Poe, especialmente por tratarse de un fenómeno conveniente a la producción de un locus horrendus, un lugar tenebroso por medio del cual sería posible despertar en sus lectores los efectos pretendidos. Sin embargo, antes del movimiento romántico del siglo XIX, el incidente marítimo, como tópico, se mostró recurrente en diferentes géneros retórico-poéticos, especialmente en los ejemplares épicos. Se pretende, en este artículo, mapear algunas descripciones de tempestades para, en seguida, tener condiciones de analizar la manera como Poe imitó esa tradición para la elaboración de un cuento en particular, titulado Manuscrito encontrado en una botella (Manuscript Found in a Bottle), publicado en 1833.

Palabras clave: Edgar Allan Poe; tempestad; sublime; epopeya; locus horrendus.

Me miserum! Quanti montes uoluuntur aquarum!

Ovídio

Não há altas montanhas sem profundos precipícios.

Victor Hugo

Quem nunca enfrentou um vendaval forte em alto-mar näo pode fazer ideia da confusão mental provocada pelo vento e pelos esguichos de água, que nos cegam, nos ensurdecem e nos sufocam, nos impossibilitando de agir e de pensar.

Edgar Allan Poe

Quando, em 1957, os soviéticos lançaram o Sputnik, primeiro satélite artificial a entrar em órbita terrestre, Hannah Arendt vislumbrou um marco inaugural, libertador, capaz de alimentar a projeção de vida humana fora da Terra (ARENDT, 1981, p. 9). No entanto, é possível interpretar esse evento utilizando outros termos: o planeta poderia ser explorado de um ponto de vista externo. Por outras palavras, novos satélites poderiam entrar em órbita para finalidades distintas, inclusive para estudos meteorológicos. Ainda que consideremos a tecnologia de ponta de que dispomos, voltada para a prevenção e o estudo de fenômenos naturais de grande porte, muitas vezes fomos vítimas de sua imprevisibilidade, como no caso do furacão Katrina que, em 2005, apesar das medidas para evacuação da população, dei- 
xou uma trilha de destruição e morte em seu itinerário pelo litoral sul dos Estados Unidos. Várias medidas foram criadas para ajudar a compreender e categorizar esses fenômenos: no século XIX, por exemplo, foi inventada a escala Beaufort, com o intuito de classificar a intensidade dos ventos com base na sua velocidade e nos seus efeitos em terra e mar. Na década de 1970, foi criada a escala Saffir-Simpson que, por meio de cinco categorias, busca medir a força de um furacão a partir da velocidade dos ventos e do seu potencial de destruiçấo. Embora estejamos munidos de ferramentas preventivas, não há medidas totalmente eficazes quando o intuito é lidar com eventos naturais. É difícil imaginar como viviam os homens quando essa tecnologia não existia: um mundo no qual as previsóes eram feitas com base na observação a olho nu, de baixo para cima, muitas vezes do convés do navio e sem poder escapar de seus efeitos. Não é de se estranhar que, em tempos remotos, as tempestades foram encaradas como castigos lançados pelos deuses para punir a hýbris, o excesso dos homens. Se, por um lado, ela continua sendo um desafio à ciência, por outro, a tempestade tornou-se, há muito, um lugar-comum, um "fenômeno discursivo" de amplo alcance, especialmente em se tratando do gênero épico. No entanto, a despeito de as epopeias terem se transformado em ruínas, a tópica não desapareceu: continuou sendo adotada pela literatura romântica. Pretende-se compreender a maneira como esse fenômeno natural foi imitado por meio da arte de Edgar Allan Poe, não sem antes investigar algumas de suas manifestaçóes no universo da poesia épica.

\section{A tempestade épica}

Homero cantou a gesta de grandes heróis, inventando tipos como Aquiles e Odisseu, mas também retratou a fragilidade humana. A preservação do feito ilustre só seria possível por intermédio do canto inspirado, capaz de anunciar a memória e celebrar o kléos, a fama imorredoura. Na proposição/invocaçáo da Ilíada, depois de pedir o auxílio da Musa, o aedo introduziu o embate entre Aquiles, filho de Peleu, e Agamêmnon, "rei dos homens", que "tantas dores trouxe aos Aqueus/ e tantas almas valentes de heróis lançou no Hades, / ficando seus corpos como presa para cáes e aves/ de rapina, enquanto se cumpria a vontade de Zeus" (HOMERO, 2013, p. 109). Algo parecido ocorre nas liminares da Odisseia, quando Homero mencionou as dores que Odisseu padeceu, pois "foram muitos no mar/ os sofrimentos por que passou para salvar a vida,/ para conseguir o retorno dos companheiros a suas casas" (HOMERO, 2011, p. 119). A tempestade, tópica recorrente no universo épico, foi um dos grandes obstáculos a ameaçar o retorno (nóstos) do rei de Ítaca.

Com a ausência de Poseidon, que visitava os Etíopes, Zeus enviou Hermes à ilha de Calipso para libertar Odisseu depois de uma longa estada. O herói partiu com vento propício, mas o deus dos mares o avistou próximo à terra dos feácios e arquitetou uma nova série 
de infortúnios. Com o seu tridente em mãos, ele congregou as nuvens e agitou os mares, iniciando uma procela. Os ventos Euro, Zéfiro, Bóreas e Noto impediram o avanço da nau de Odisseu que, frente ao quadro que se desenhava à sua volta, exclamou:

Ai, pobre de mim! O que estará para me acontecer?

Receio que seja verdade tudo o que me disse a deusa:

pois ela me declarou que, antes de chegar à terra pátria,

no mar teria eu muito que sofrer. Tudo isso agora se cumpre,

tais são as nuvens com que Zeus coroa o vasto céu.

E agitou também o mar, fazendo colidir as rajadas

de toda a espécie de ventos. A morte escarpada está garantida.

Ó três e quatro vezes bem-aventurados os Dânaos,

que morreram na ampla Troia para fazer um favor aos Atridas!

Quem me dera que com eles tivesse também eu perecido

naquele dia em que contra mim investiam com brônzeas lanças

os Troianos, pelejando em torno de Aquiles já morto.

Teria tido ritos fúnebres e minha fama teriam espalhado os Aqueus.

Meu destino é agora ser tomado por uma morte deplorável

(HOMERO, 2011, p. 204-205).

Uma onda robusta precipitou-se contra a jangada, lançando o herói ao mar. O mastro partiu-se em dois, forçado pela "força terrível das rajadas da tempestade", e somente com grande dispêndio de energia, Odisseu conseguiu vencer as ondas e retornar à embarcação. A deusa Ino, protetora dos marinheiros, aconselhou-o a abandonar a nau e seguir a nado rumo à costa da Esquéria. Atena, por sua vez, refreou os ventos, mas o rei de Ítaca passou dois dias nadando contra a maré até chegar a seu destino: "muitas vezes diante do coração lhe surgia a morte" (p. 208). Dois lugares-comuns fundamentam os fragmentos supracitados: o lamento do protagonista, que receava uma morte mísera e inglória, porque destituída de honras fúnebres, e a "visualização" da morte como forma de amplificar o drama e o perigo vivenciados no momento do incidente marítimo.

Emulando a epopeia homérica, Virgílio se constituiu como auctoritas do gênero com sua Eneida, poema cuja leitura tornou-se imperativa nos círculos letrados, não apenas sob o império de Augusto, mas nos séculos que o sucederam. Planejando a queda de Eneias e de seus homens, Juno descera à morada de Éolo, que imperava sobre "ventos e ruidosas tempestades, e com grilhóes e cárcere os refreia". A deusa pediu-lhe que libertasse os ventos e afundasse as naus troianas, oferecendo-lhe em troca a mais bela das ninfas, Deiopeia. Éolo atendeu ao pedido e, com sua lança, instigou os ventos. Densas nuvens "o céu e o dia de repente ocultam aos olhos dos troianos". Todo o ar "com crebros raios resplandece: tudo a morte apresenta 
aos navegantes". Virgílio mobilizou a tópica que Homero utilizou para amplificar os perigos relativos à tempestade e, na sequência, o lamento de Eneias em meio à procela mostrou-se compatível com o de Odisseu:

Oh mil vezes, exclama, venturosos

Os que de Troia junto aos altos muros

À vista de seus pais morrer puderam!

Oh de todos os Dâneos o mais forte,

Tidides, que eu a sorte não tivesse

De nos campos Ilíacos, pugnando,

Sucumbir do teu braço aos duros golpes,

E o espírito exalar! onde prostrado

Jaz o valente Heitor do Aquíleo ferro,

Onde o ingente Sarpédon, onde tantos

Escudos, capacetes, e robustos

Corpos d'heróis nas ondas volve Símois

(VIRGÍliO, 2004, p. 9).

A imitação se efetuou na maneira como o lamento se constituiu e por meio dos exemplos referidos, que também remetem aos poemas homéricos. Na sequência, Aquilão rompeu-lhe a vela, os remos se despedaçaram e a nau ficou à mercê das ondas, que se erguiam como "um monte", abrindo um "largo hiato" no mar. Noto arremessou três embarcaçôes contra "cegos penedos" e Euro encalhou outras três em "baixas Sirtes". A nau dos Lícios, após três redemoinhos, foi devorada pelo mar, e as de Ilioneu, Acates e Abas foram destroçadas pelo temporal: "abertas as junturas dos lados, por mil rombos as inimigas ondas vão bebendo". João Manuel Nunes Torrão disse que, por meio das exclamaçôes de Eneias, é possível inferir que estivesse desejando a morte (TORRÃO, 2000, p. 648). Não seria, todavia, o kléos (ou a fama perene) o objeto de desejo do herói? Eneias não desejava morrer: valendo-se do lugar-comum já detectado em Homero, ele afirmou que os guerreiros mortos em campo de batalha depois de enfrentarem um oponente ilustre, como era o caso de Tidides, Heitor e Sarpédon, foram agraciados com a glória negada àqueles que sucumbiram vitimados por uma tempestade. A mesma tópica se faz presente na tragédia Agamêmnon, de Sêneca, quando a personagem Euríbades foi encarregada de narrar os infortúnios marítimos que atingiram as tropas gregas após a guerra de Troia. Os nautas, sob ameaça de uma morte desprovida de honras, lamentaram:

[...] Pirro inveja o pai,

Ulisses, a Ájax, o mais jovem Atrida, a Heitor, 
a Príamo, Agamêmnon; ao que jaz em Troia, feliz o chamam, quem morrer logrou em luta, quem a fama eterniza e o chão vencido cobre (VIRGÍlLIO, 2004, p. 63).

José Eduardo Lohner afirma que a tempestade, em Agamêmnon, seria uma mescla de relato trágico e épico. Quanto à sua formulação, Sêneca teria imitado Virgílio e Ovídio, muito embora para sustentar um sentido alegórico, representando a ira de Clitemnestra contra o rei dos aqueus (LOHNER, 2009, p. 12).

No século VI, o poeta cristão Arátor escreveu, com versos hexâmetros, De Actibus Apostolorum (História Apostólica). O poema volta-se para a gesta evangelizadora dos dois grandes "pilares da Igreja”: São Pedro e São Paulo. Portugueses do século XVI conheceram o poema por meio de Aires Barbosa que, em 1516, publicou o texto original e analisou seu conteúdo (MANSO, 2010, p. 13). Na seção XVII do livro II, o poeta tratou do episódio da tempestade que acometeu Paulo quando ele seguia rumo à Itália:

\section{[...] Logo a quietude do pélago}

foi quebrada pelos sopros do Euro, e a paz fingida do mar cerúleo embranqueceu em inchadas ondas. Por todo o lado o mar se enfurece e, levantando a sua massa do abismo irado, nega uma rota segura ao navio em apuros, que, elevado até aos astros e daí precipitado, se une ao mar, seguidor da terra e do céu. A mão hábil para a navegação carece da ajuda de uma arte amiga, perdem o ânimo por causa do gélido pavor e, cegos sob o negro nevoeiro, veem o naufrágio iminente e, nas profundezas cerradas, aparece a imagem da morte (ARÁTOR, 2010, p. 12).

José Manso, responsável pela tradução do poema, assegura que a versificação dos Atos dos apóstolos não impediu Arátor de imitar a Eneida, algo fácil de ser constatado quando se analisa o episódio envolvendo a tempestade: a princípio, o poeta recorreu a imagens topográficas para formular a hipérbole por meio da qual associou o mar a um "abismo irado"; com a figura da prosopopeia, ele atribuiu vida aos ventos e sentimentos ao mar (fingido, furioso, irado); por fim, ele trabalhou com a ideia da morte enquanto imagem circundante em meio ao "negro nevoeiro" que, além disso, sugeria a iminência do naufrágio.

No poema De Gestis Mendi de Saa (1563), atribuído ao padre jesuíta José de Anchieta, as metáforas topográficas foram igualmente evocadas, como no momento em que o narrador afirmou que o vento sul "se atira torcendo em vórtices as ondas/ e sacode em turbilhôes hor- 
rendos o mar tenebroso,/ que se enfurece ao peso da borrasca, ergue em montanha/ as águas turvadas e as lança raivoso às alturas" (ANCHIETA, 1986, p. 187). A ideia de uma morte espectral foi igualmente requisitada para amplificar o drama que acometia a marinhagem: "O terror invade a todos e a todos agita. Entra o medo, já tremem de horror e o espectro da morte se agarra teimoso aos olhos espavoridos da gente" (p. 187). O lamento dos nautas não tardou, seguindo de perto o cânone épico: "Pai bondoso dos céus e tu, Cristo benigno,/ que nos preparas? dizei-nos: permitirás que morramos/ no meio das ondas, ó Pai? que sejamos vil pasto/ dos peixes vorazes" (p. 189). Temiam, como era de se esperar, um fim ruinoso tragados pelo "negro abismo dos mares".

Em Os lusíadas, o mestre da nau foi o primeiro a notar uma nuvem negra e a mudança repentina dos ventos. A procela iniciou-se subitamente. $\mathrm{O}$ responsável por ela foi Baco, que pediu a Éolo a intervenção dos ventos. O mestre ordenou o recolhimento das velas, mas os ventos não esperaram e "em pedaços a fazem cum ruído que o mundo pareceu ser destruído". O céu "fere com gritos nisto a gente, cum súbito temor e desacordo". O mestre, depois de lançar o alerta e mandar amainar, pediu aos marinheiros para alijarem tudo ao mar e trabalharem nas bombas, pois a nau estava alagada. Os nautas atenderam ao pedido com presteza, mas os "mares temerosos" os derribaram. A metáfora mobilizada para retratar a força dos ventos, desta vez, é bíblica:

Os ventos eram tais, que não puderam

Mostrar mais força de ímpeto cruel,

Se pera derribar então vieram

A fortíssima Torre de Babel.

Nos altíssimos mares, que cresceram,

A pequena grandura dum batel

Mostra a possante nau, que move espanto,

Vendo que se sustém nas ondas tanto

(CAMÓES, 2008, p. 192).

A Torre de Babel foi referida para substituir a recorrente imagem da montanha, atendendo ao mesmo intuito amplificador. Em outra oitava, a amplificação repetiu os procedimentos metafóricos há pouco aludidos:

Agora sobre as nuvens os subiam

As ondas de Netuno furibundo;

Agora a ver parece que desciam

As íntimas entranhas do profundo.

Noto, Austro, Bóreas, Áquilo queriam 
Arruinar a máquina do mundo;

A noite negra e feia se alumia

Cos raios em que o Pólo todo ardia (p. 192).

O quadro dramático estava desenhado e Vasco da Gama, frente às intempéries, recorreu a remédio "santo e forte" e lamentou, como era costumeiro, a morte em alto-mar:

Vendo Vasco da Gama que tão perto

Do fim de seu desejo se perdia,

Vendo ora o mar até o Inferno aberto,

Ora com nova fúria ao céu subia,

Confuso de temor, da vida incerto,

Onde nenhum remédio lhe valia,

Chama aquele Remédio santo e forte,

Que o impossível pode, desta sorte:

"Divina Guarda, angélica, celeste,

Que os Céus, o Mar e Terra senhoreias:

$\mathrm{Tu}$, que a todo Israel refúgio deste

Por metade das águas Eritréias;

Tu, que livraste Paulo e defendeste

Das sirtes arenosas e ondas feias,

E guardaste, cos filhos, o segundo

Povoador do alagado e vácuo mundo:

Se tenho novos medos perigosos

Doutra Cila e Caríbdis já passados,

Outras Sirtes e baxos arenosos,

Outros Acroceráunios infamados,

No fim de tantos casos trabalhosos,

Por que somos de Ti desamparados,

Se este nosso trabalho não Te ofende,

Mas antes Teu serviço só pretende?

Oh! Ditosos aqueles que puderam

Entre as agudas lanças Africanas

Morrer enquanto fortes sustiveram

A santa Fé nas terras Mauritanas! 
De quem feitos ilustres se souberam,

De quem ficam memórias soberanas,

De quem se ganha a vida, com perde-la,

Doce fazendo a morte as honras dela!” (p. 193-194)

Além da passagem dos hebreus pelo Mar Vermelho, Camóes mencionou a tempestade bíblica que acometeu Paulo e o dilúvio narrado em Gênesis. Com o propósito de retratar o terror vivenciado pelos marinheiros, o poeta imitou a Eneida ao descrever o movimento das ondas. Assumindo postura análoga à de Atena na Odisseia, Vênus foi a responsável pelo abrandamento da fúria dos ventos, que atacavam a nau como "touros indômitos". No que se refere ao lamento, Camôes seguiu de perto a tópica antiga, a valorizar aqueles que tombaram em campo de batalha vitimados pelas "agudas lanças Africanas", premiados com uma morte doce e honrosa, em detrimento daqueles que perderam a vida em um naufrágio.

\section{Poe e a descrição da tempestade}

Edgar Allan Poe nasceu em Boston, Massachusetts, no dia 19 de janeiro de 1809. Foi abandonado pelo pai quando tinha apenas um ano de idade e perdeu sua mãe para a tuberculose no ano seguinte. Uma família de comerciantes residente em Richmond, Virgínia, ficou com a guarda do garoto. Depois de uma adolescência conturbada, alistou-se no exército de Boston. Quando de seu retorno, ele quase foi vítima de um naufrágio na costa do Cabo Cod, o que poderia ter inspirado seu conto de 1833 intitulado "Manuscript found in a bottle" ("Manuscrito encontrado em uma garrafa"), que lhe conferiu seu primeiro prêmio literário em concurso promovido pelo The Saturday Visiter. Suas narrativas voltam-se para diferentes enfoques: "O escaravelho de ouro" (1843), por exemplo, apresenta uma história aventuresca voltada para a busca de um tesouro perdido; "Os assassinatos na rua Morgue" (1841) é o primeiro de uma série de contos protagonizada pelo excêntrico detetive Auguste Dupin; "O poço e o pêndulo" (1842) figura a ideia de tortura por meio de um homem condenado pela Inquisiçẫo; "O gato preto" (1843) e "O coração delator" (1843) assumem um tom mais funesto ao retratar a narrativa de homicidas; "Uma descida ao Maelström" (1841) e "O enterro prematuro" (1844) abordam situaçôes extremas nas quais os narradores vivenciaram experiências que, por pouco, não causaram suas mortes; "Breve colóquio com uma múmia" (1845) e "O demônio da perversidade" (1845) expõem situaçôes de feição mais próxima ao grotesco. Como se pode notar, há uma grande variedade, e não mencionamos sequer a metade das narrativas que tomaram forma sob a pena de Edgar Allan Poe. Talvez as palavras de seu mais ávido panegirista ajudem a compreender seu gênio multívio: 
Nenhum homem jamais contou com maior magia as exceçóes da vida humana e da natureza; os ardores de curiosidade da convalescença; o morrer das estaçóes sobrecarregadas de esplendores enervantes, os climas quentes, úmidos e brumosos, em que o vento sul amolece e distende os nervos, como as cordas de um instrumento, em que os olhos se enchem de lágrimas que não vêm do coração; a alucinação deixando, a princípio, lugar à dúvida, para em breve se tornar convencida e razoadora como um livro; o absurdo se instalando na inteligência e governando-a com uma lógica espantosa; a histeria usurpando o lugar da vontade, a contradição estabelecida entre os nervos e o espírito, e o homem descontrolado, a ponto de exprimir a dor por meio do riso. Analisa o que há de mais fugidio, sopesa o imponderável e descreve, com essa maneira minuciosa e científica, cujos efeitos são terríveis, todo esse imaginário que flutua em torno do homem nervoso e o impele para a ruína (BAUDELAIRE, 2017, p. 28).

Como já adiantamos, o objeto de nosso estudo é um breve texto publicado em 1833 com o título "Manuscrito encontrado em uma garrafa". O narrador, no princípio do conto, afirma não passar de um exilado favorecido pela fortuna: recebeu uma grande herança que lhe proporcionou "educação extraordinária". Era reconhecido por seu gênio árido, por uma imaginação deficiente e por seu ceticismo. Por essa razão, alegou que nenhuma pessoa poderia ser menos suscetível do que ele "a ser afastado dos severos preceitos da verdade pelo ignes fatui da superstição" (POE, 2017, p. 274). Os termos adotados reforçam a antiga tópica da modéstia afetada, ou seja, trata-se de um argumento capaz de reafirmar a veracidade do relato com base na aridez ou na indisposição para florear do narrador, o que tornaria improvável o "devaneio de uma imaginação fértil". Tal lugar-comum, além de atribuir fidedignidade ao conto, efetua a captatio benevolentiae, a captação da benevolência do leitor que, possivelmente, seguiria a leitura intrigado. Não há, portanto, novidade no procedimento presente em seu proêmio, mas sim no modo como Poe referiu-se à imaginação como objeto do fazer literário. $\mathrm{O}$ relato inacreditável a ser contado, baseado na "experiência concreta de uma mente para qual os enleios da fantasia sempre foram irrelevantes e nulos" (p. 274), reforça o valor do testemunho e, assim, reafirma outra tópica, presente em Tucídides e nos historiadores antigos de forma geral, por meio da qual a visão é referida como sentido primordial na produçáo de conhecimento.

Ao iniciar a narrativa, Poe afirma que, na primeira metade do século XIX, um marinheiro experiente partiu do porto da Batávia, situado em Java, uma das ilhas que integram o Arquipélago de Sonda. Dominado por uma inquietação que o assombrava, tripulou um navio de quatrocentas toneladas carregado com algodão, óleo das ilhas Laquedivas, fibras de coco, cana-de-açúcar e outros produtos mal armazenados que deixaram a embarcação instável. A viagem, monótona nos primeiros dias, subitamente tornou-se cenário de prodígios: a lua apresentava um aspecto sombrio e avermelhado, o mar passou a ostentar um aspecto peculiar e o ar aqueceu-se repentinamente. A noite trouxe consigo o cessar dos ventos e uma calmaria duradoura. Perante esse cenário, o capitão não demonstrou preocupação, orde- 
nando o recolhimento das velas e o lançamento da âncora. Diferentemente da tripulação, o narrador foi tomado por um "pressentimento terrível de catástrofe", prevendo o advento de um temporal. $\mathrm{O}$ capitão não lhe deu razão, mas o marinheiro não conseguiu pregar os olhos. Por volta da meia-noite, quando subia rumo ao convés, uma torrente furiosa varreu toda a cobertura do navio, da proa à popa, deixando somente dois sobreviventes: o autor do relato e um sueco. Ao ficar de pé, notaram que o "redemoinho produzido por aquele oceano montanhoso e espumante" no qual estavam imersos "era aterrorizante e sobrepujava a mais desvairada imaginação" (p. 276). Mais uma vez, amplifica-se o terror da experiência reafirmando a impossibilidade de sequer imaginá-la. A ideia de um "oceano montanhoso" remete à metáfora topográfica que detectamos na descrição de várias tempestades épicas. Uma sucessão de adjetivos contribuiu com a edificação de um locus horrendus:

Embora a tempestade continuasse a nos fustigar com violência incessante, não havia mais indícios da habitual aparição da arrebentação ou da espuma que nos seguira até ali. Ao redor, tudo era horror, densa escuridão e um escaldante deserto negro. Aos poucos, o terror sobrenatural tomou conta do espírito do velho sueco e minha própria alma também se viu envolta em silencioso assombro (p. 277).

Nesse momento, os sobreviventes se deram conta de que avançaram para o Sul, singrando águas nunca antes visitadas. Além de ser possível uma analogia com a noção grega de hýbris, isto é, de uma ação descomedida passível de punição, constata-se a figuração do insólito, de um cenário novo que poderia proporcionar experiências igualmente inéditas. Foi o que o narrador tentou retratar ao afirmar que, às vezes, ficavam sem ar "suspensos em uma elevaçáo que excedia o voo do albatroz" (p. 278). Trata-se de uma analogia cujos efeitos hiperbólicos tendem a agravar o perigo reinante. Em outros momentos, os marinheiros sentiam "a vertigem da descida brusca em direção a algum inferno marítimo, onde o ar estagnava e nenhum som perturbava o sono do Kraken" (p. 278). Embora a referência à mitologia nórdica seja explícita, a ideia de um "inferno marítimo" apareceu também na epopeia lusíada para amplificar o poderio das ondas.

Foi nesse instante que o sueco avistou algo: um navio de cerca de quatro mil toneladas (ou seja, dez vezes mais pesado do que aquele que tripulavam) com porte superior a todos a serviço da Companhia das Índias. O choque entre os dois navios precipitou o narrador para a outra embarcaçáo. Depois de ocultar-se no poráo, longe dos olhares de nautas cuja procedência desconhecia, ele relatou suas impressóes:

Um sentimento inominável apossou-se de minha alma - uma sensação que não permite nenhum tipo de análise, para a qual as liçôes do passado são inadequadas e, receio, o futuro não ofertará resposta alguma (...). Uma nova sensaçáo - uma nova entidade foi acrescida à minha alma (p. 280). 
O narrador menciona sua incapacidade de estabelecer qualquer analogia com ocorrências pretéritas e, simultaneamente, denuncia a insuficiência da historia magistral vitae, da história mestra da vida. No entanto, depois de observar com cuidado a estrutura do navio e suas particularidades, ele é tomado por uma "sensação de familiaridade", vislumbrando "sombras indistintas de recordação" possivelmente decorrentes de "crônicas estrangeiras de eras passadas" (p. 281). Seria um navio fantasma? Por isso, mesmo circulando por toda a embarcação, o protagonista não foi notado? Estaria morto? Os nautas, diga-se de passagem, apresentavam idade avançada e manuseavam instrumentos matemáticos de construção excêntrica e obsoleta. "Decerto estamos condenados a pairar continuamente à beira da eternidade, sem nos precipitarmos em um derradeiro mergulho no abismo" (p. 282). O fragmento confirma a ideia da morte, ou simplesmente amplifica um intervalo de tempo que, de tão aterrorizante, parecia durar para sempre, como uma pintura capaz de, numa cena, suspender o tempo e retratar algo sublime? Não poderia faltar, na sequência, um toque sobrenatural, ainda que seu sentido fosse metafórico:

Fustigados por ondas mil vezes mais assombrosas do que as que já vi, deslizamos com velocidade fácil da gaivota e as águas colossais erguiam suas cabeças sobre nós como demônios das profundezas, mas como demônios limitados a simples ameaças e proibidos de nos destruir (p. 282).

O fragmento acima, após amplificar o terror com uma hipérbole numérica (mil vezes), se incumbe de atenuá-lo, de modo a justificar a perseverança do navio. Em outro conto, "Uma descida ao Maelström" (1841), Poe recorre a uma descrição que intensifica igualmente a dimensão das ondas:

Quando um barco é bem construído, está mareado e não transporta carga muito pesada, as ondas durante um vendaval forte parecem deslizar para baixo de seu casco... o que parece estranho aos olhos dos leigos - mas que nós chamamos de "cavalgada". Ora, até ali tínhamos cavalgado bem as ondas, mas de repente um vagalhão gigantesco nos atingiu por trás, carregando a sumaca enquanto se erguia mais e mais alto, como se quisesse subir aos céus. Era inacreditável que uma onda pudesse se elevar àquela altura. Então despencamos, deslizando rumo ao mergulho. Fiquei nauseado e tonto, como se tivesse caído do pico de uma montanha em sonhos (POE, 2018, p. 135).

A figura adotada, dessa vez, foi um símile: uma comparação entre o mergulho do navio, após ser erguido por uma onda, e a queda vertiginosa do pico de uma montanha. Mas, em outro fragmento, adota-se a boa e velha metáfora topográfica: "O mar, porém, que no início fora subjugado pelo vento e se mantivera espumante, mas sem ondas, agora se erguia em ver- 
dadeiras montanhas" (p. 134-135). Nesse conto, em particular, a pesada atmosfera de terror trouxe para o pescador que sofria os males da intempérie uma calma excepcional: "Quando nos vimos nas garras da voragem, fiquei mais calmo do que estava durante o temerário percurso" (p. 136). O modo como ele encarou a perspectiva de morrer em alto-mar inverteu a tópica antiga do lamento dos marinheiros:

Não estou querendo me exibir, apenas relatando a mais pura verdade. Comecei a ponderar que morrer daquele jeito deveria ser algo formidável e quão tolo e mesquinho de minha parte era pensar apenas na minha vida, diante de uma manifestação tấo espetacular do poder de Deus. Creio ter ruborizado de vergonha quando essa ideia cruzou minha mente. Fui então tomado por uma curiosidade profunda sobre o redemoinho em si. Experimentei um desejo genuíno de explorar suas profundezas, mesmo que para isso tivesse que sacrificar a própria vida. Meu maior desgosto era jamais poder relatar aos meus velhos amigos em terra firme os mistérios que estava prestes a desvendar (p. 136).

Diferentemente de Odisseu, Eneias e Vasco da Gama, que lamentaram a morte em alto-mar porque ela impediria os rituais fúnebres e a obtenção de fama, o pescador, prestes a ser tragado pelo redemoinho, deixou sua curiosidade superar o terror a ponto de considerar a morte um preço justo a se pagar, contanto que pudesse testemunhar aquela espetacular manifestação do poder de Deus. Seu único desgosto seria o de não poder transmitir sua experiência, um receio que se mostrou desnecessário já que pôde legar aos pósteros detalhes de sua façanha.

Dando prosseguimento à intriga do "Manuscrito", o narrador busca, a todo momento, transmitir ao leitor o caráter inédito de sua experiência e compartilhar algo que ele denominou sem nomear:

o navio e tudo nele estáo imbuídos com o espírito da Antiguidade. A tripulaçáo desliza de um lado para o outro como uma turba espectral de séculos sepultados; os marinheiros têm olhos ávidos e inquietos e, quando seus vultos cruzam meu caminho, no fulgor fantástico das lanternas de batalha, sou tomado por uma sensação inédita (POE, 2017, p. 283).

Poe estaria sepultando a história ou simplesmente afirmando que da história restam somente ruínas ou, em suas palavras, uma "turba espectral de séculos sepultados"? Por isso os tripulantes falavam uma língua incompreensível e apresentavam um aspecto fantástico? Ou trata-se de recursos estéticos capazes de aprimorar a descrição, tornando-a vívida, sublime e deleitosa?

Em um texto de 1846 no qual avaliou a composição de um poema de sua autoria intitulado The raven (1845), Poe levanta algumas questóes que podem ajudar a compreender o conto do qual nos ocupamos. 
Parece-me bem claro que qualquer enredo digno de nota deva ser elaborado com seu desdobramento em mente antes mesmo de ser escrito. Somente não descuidando do desenrolar da trama que podemos conferir ao enredo um indispensável ar de consequência, de relação causal, fazendo com que os incidentes - e sobretudo, o tom geral da obra - contemplem o desenvolvimento de uma ideia (POE, 2017, p. 341-342).

A princípio, o autor afirma que é preciso considerar o efeito. Mantendo a "originalidade" em vista, há uma pergunta que ele julga imprescindível: "Dos inúmeros efeitos e impressões aos quais o coração, o intelecto ou (de forma mais geral) a alma é suscetível, qual devo selecionar para a presente ocasião?” (p. 342). De preferência, há que se optar por um efeito original e vívido, ele diz: um efeito caracterizado pelo entusiasmo, capaz de "elevar a alma" com intensidade e brevidade. Em seguida, ele assegura que a beleza é algo que deve ser perseguido, pois proporciona "o mais intenso, elevado e puro de todos os prazeres" (p. 344-345). Ele concebe a beleza como um efeito, e não como uma qualidade: o caminho mais eficaz para a elevação da alma. A melancolia, por sua vez, seria o "mais legítimo de todos os tons poéticos" (p. 345).

Há, segundo Kant, ligação entre a melancolia e o sublime, uma associação que parece fazer sentido na produção literária de Edgar Allan Poe. De acordo com o filósofo alemão, todo aquele

cujo sentimento cai facilmente no estado melancólico, não é assim chamado por, estando privado das alegrias de viver, se consumir numa taciturnidade sombria, mas porque quando os seus sentimentos se intensificam excedendo um certo limite, ou quando ganham uma direção errada devido a certas causas, estes podem mais facilmente conduzir a este estado do que a qualquer outro. Neste estado revela-se, sobretudo, uma sensibilidade do sublime (KANT, 2012, p. 47).

Pretende-se, no tópico seguinte, compreender melhor o conceito de sublime para, em seguida, tirar conclusóes a respeito da maneira como Poe empregou a tempestade em seu conto.

\section{A estética do sublime}

O mais antigo tratado sobre o sublime de que se tem notícia, escrito no século III d. C., foi atribuído a Longino, que o concebeu como um efeito arrebatador causado por passagens bem elaboradas e capazes de desarmar o leitor, subjugando-o. No capítulo X, o autor menciona a descrição das tempestades como exemplo de manifestação do sublime, detendo-se numa passagem de Homero presente na Ilíada: "uma onda inchada pelos ventos rebenta 
sobre a nau veloz,/ e toda ela é coberta pela espuma e a rajada terrível do vento/ grita contra a vela e tremem os espíritos dos marinheiros,/ aterrorizados; pois por pouco dali foram levados da morte" (HOMERO, 2013, p. 453). O parentesco, portanto, entre as tempestades épicas e a noção antiga de sublime mostra-se verossímil, sendo o incidente marítimo um evento encarado como capaz de arrebatar e comover os leitores.

Autores ingleses do século XVIII, quando abordaram o assunto, não atribuíram mais à arte, mas à natureza e seus fenômenos, a capacidade de proporcionar um efeito sublime. Dito de outro modo, o sublime passou a decorrer de fenômenos naturais, e não mais de metáforas ou de outras figuras elaboradas com finalidades poéticas. Essa transposição já pode ser detectada num texto de 1712, intitulado Os prazeres da imaginação, de Joseph Addison, que chegou a afirmar que o mar, quando calmo, lhe proporcionava um espanto prazeroso, e uma sensação de horror agradável surgia da contemplação de uma tempestade. Mas foi com a obra Uma investigaçáo filosófica sobre a origem de nossas ideias do sublime e do belo, de Edmund Burke, publicada em 21 de abril de 1757, que a noção ganhou ampla repercussão nos círculos letrados. Quando elaborou sua reflexáo sobre o gosto, concebido como elemento constituinte da natureza humana, o autor voltou-se para os fundamentos do belo e do sublime, partindo do pressuposto de que o gosto e a imaginação seriam regulados por princípios predefinidos e universais. Sendo assim, ele seria uma faculdade do espírito afetada pelas obras da imaginação e pelas belas artes, conferindo ao homem a capacidade de julgá-las. Os sentidos, portanto, viriam a apreender os objetos exteriores, restando à imaginação associar as imagens produzidas e ao juízo tirar dessa associação um entendimento. ${ }^{1}$

O sublime foi entendido como algo "capaz de incitar as ideias de dor e de perigo" (BURKE, 1993, p. 48). O que se apresenta de "maneira terrível”, relaciona-se a objetos terríveis ou atua de modo análogo ao terror constitui, no caso, fontes do sublime. Quando o perigo ou a dor se apresentam como "uma ameaça decididamente iminente", eles não são capazes de proporcionar deleite, mas somente terror. O deleite não corresponde ao "prazer positivo" gerado pelo belo, mas trata-se da "sensação que acompanha a eliminaçáo da dor ou do perigo" e, por essa razão, está estritamente ligada à noção de sublime, da mesma forma como o prazer se associa à noção de belo (p. 46). Noutro momento, Burke acrescenta que não somente aquilo que é capaz de suscitar terror pode servir de base para o sublime, mas também coisas "que não oferecem nenhum perigo aparente produzem um efeito semelhante, dado que atuam de maneira análoga" (p. 137). O sublime, por fim, é a soma de partes desarmônicas e discordes, com variaçôes bruscas, cores fortes, dimensôes físicas desproporcionais.

\footnotetext{
${ }^{1}$ A imaginação, para Burke, seria uma faculdade criativa incumbida de apreender os objetos e combinar imagens das coisas apreendidas. Além disso, ela mostra-se a mais ampla esfera do prazer e da dor, pois é por meio dela que atribuímos forma a nossos temores e esperanças. Assim, somos capazes de recepcionar objetos externos de formas distintas no que diz respeito ao grau, na medida em que os hábitos interferem na sua recepção, mas a origem da impressão e a maneira como somos afetados seriam inatas, universais.
} 
Para gerar os efeitos esperados em sua audiência, um poeta deveria levar em conta a "simpatia", definida por Burke como "uma espécie de substituição, mediante a qual colocamo-nos no lugar de outrem e somos afetados, sob muitos aspectos, da mesma maneira que eles". Para o autor, é por meio desse princípio que "a poesia, a pintura e as outras artes relacionadas a sentimentos comunicam suas paixões de um coração a outro e muitas vezes são capazes de enxertar um deleite no desgosto, na infelicidade e na própria morte" (p. 52-53). O objetivo da poesia, em particular, é "impressionar mais pela simpatia do que pela imitação" e "reforçar o efeito das coisas sobre o espírito do orador ou dos ouvintes" (p. 177). A simpatia, portanto, é o elemento natural que nos leva a experienciar o deleite ao contemplar o sofrimento alheio: "Não há espetáculo que busquemos com tanta avidez quanto o de alguma desgraça incomum e atroz; portanto, quer a desdita ocorra diante de nossos olhos, quer ela se passe na história, sempre nos provoca deleite" (p. 54).

Vários elementos, ao longo do tratado, são apontados como capazes de suscitar o sublime, como é o caso da obscuridade, pois quando "temos conhecimento de toda a extensão de um perigo, quando conseguimos que nossos olhos a ele se acostumem, boa parte da apreensão desaparece" (p. 66). A noite, para Burke, é um cenário igualmente apropriado para provocar terror. Além disso, ao invés de recorrer à clareza discursiva, o autor optou por ideias impressionantes que alimentariam a imaginação, pois seriam capazes de suscitar emoçôes mais fortes, como nos casos de descriçôes verbais vívidas e expressivas. As privaçôes são igualmente grandiosas, como é o caso do vazio, das trevas, da solidão e do silêncio, assim como a grandiosidade de dimensôes, poderosa fonte do sublime. A infinitude, por sua vez, "tem uma tendência a encher o espírito daquela espécie de horror deleitoso, que é o efeito mais natural e o teste mais infalível do sublime" (p. 78). Convém mencionar, por fim, a magnificência, decorrente da profusão de coisas esplêndidas e, preferencialmente, desordenadas, como o céu estrelado, a luz, que poderia suscitar o sublime, como no caso de relâmpagos, graças à sua velocidade, e ruídos intensos, como os de "grandes cataratas, tempestades ululando, trovão ou artilharia".

Edgar Allan Poe atendeu a quase todos esses requisitos quando formulou sua descrição da tempestade: adotou um cenário noturno desprovido de luz, referiu os ruídos produzidos pela procela e o sibilar dos ventos, ${ }^{2}$ apresentou cenas obscuras e episódios impressionantes como a aparição do navio "fantasma", mencionou a grande dimensão das trevas que se espalhavam ao redor e descreveu com minúcias o movimento das ondas e da nau entregue ao acaso da intempérie. Poder-se-ia objetar, alegando que os elementos elencados já se fizeram presentes em textos mais recuados, especialmente por meio das figuras de linguagem: mudança brusca da luz para trevas, apreciação do grandioso e magnífico, descrições de ruídos

\footnotetext{
2 "Tentei falar com meu irmão uma ou duas vezes. No entanto, sem que eu pudesse compreender o porquê, o barulho aumentara tanto que não pude fazê-lo entender uma só palavra, mesmo berrando ao seu ouvido" (POE, 2018, p. 135).
} 
assombrosos, dentre outros artifícios, compuseram a tempestade descrita por Camóes, por exemplo. Se é assim, o que há de realmente novo na promoção dessa "estética do gênio" ou, caso se prefira, dessa reflexão sobre o gosto?

Convém recordar que, no conto de Poe, o narrador principiou seu relato alegando que não passava de um exilado, um expatriado, mostrando-se um solitário. Além disso, ele se viu envolvido em trevas e visitando paragens secretas, até aquele momento impenetráveis. Mais uma vez, o autor aproxima-se do sublime, dessa vez em conformidade com os preceitos de Schiller. Para o filósofo alemão, apenas por meio da compaixão, um sentimento inato, poder-se-ia experimentar o sofrimento alheio sem ser destruído por ele. Só por meio da arte o sublime patético seria possível. A arte, para ele, é inteiramente livre e, por isso mesmo, "possui todas as vantagens da natureza, sem partilhar seus grilhôes" (SCHILLER, 2011, p. 74). Nesse momento, há um rompimento com a tradição inglesa que concebia o sublime como desdobramento de fenômenos naturais e uma aproximaçáo com o tratado de Longino.

\section{Tradição e inovação}

O grotesco, no século XIX, passou a ser concebido como um dos mecanismos capazes de proporcionar um efeito sublime. Em um prefácio escrito em 1827, Victor Hugo refletiu sobre a arte por meio de três momentos históricos: (1) os tempos primitivos, momento no qual não havia propriedades, leis ou guerras. $O$ poeta, a essa altura, era jovem e adotou o gênero lírico como referência; (2) os tempos antigos, circunstância na qual a família tornou-se tribo e a tribo uma nação; o acampamento deu lugar à cidade e o cajado dos pastores assumiu o aspecto de cetro. A sociedade patriarcal foi sucedida por uma sociedade teocrática, em que o sacerdote e o rei dividiram entre si a paternidade do povo. O gênero épico foi apropriado a esse momento, pois testemunhou-se a disputa entre impérios, guerras, viagens etc. Mesmo os poetas trágicos do mundo antigo, para Victor Hugo, buscaram inspiração no "rio homérico"; (3) os tempos modernos, momento no qual a religiáo tornou-se completa, ensinando ao homem que ele tem duas vidas, uma passageira e outra imortal. $\mathrm{O}$ cristianismo criou uma distância entre Deus e os homens e os poetas foram inspirados por um ingrediente decisivo, um sentimento que é "mais que a gravidade e menos que a tristeza: a melancolia" (HUGO, 2014, p. 23). Para Hugo, Longino e Santo Agostinho encontram-se nas extremidades dessa transiçãa.

De acordo com o autor, a grande questáo é o abismo existente entre uma literatura clássica e outra, romântica. O gênio moderno, para ele, nasceu de uma fusão entre o tipo grotesco e o tipo sublime. Apesar de encontrar, na Antiguidade, a manifestação tímida do grotesco, foi no pensamento dos Modernos que ele adquiriu um papel fundamental. Foi ele, segundo o autor, que conferiu a Satã seus cornos, os pés de bode e as asas de morcego. A harmonia entre contrários ditava o tom da nova literatura, do romantismo. "Vê-se como a arbitrária 
distinção dos gêneros se desmorona depressa diante da razão e do gosto” (p. 51). Era preciso, para ele, destruir a carunchada "viga do velho casebre escolástico", acabar com a "lei fundamental do código pseudo-aristotélico". Sendo assim, ele insistiu:

Destruamos as teorias, as poéticas e os sistemas. Derrubemos este velho gesso que mascara a fachada da arte! Não há regras nem modelos; ou antes, não há outras regras senão as leis gerais da natureza que plainam sobre toda a arte, e as leis especiais que, para cada composição, resultam das condiçóes de existência próprias para cada assunto (p. 64).

Voltando à tempestade retratada por Poe, é possível perceber que ele adotou várias técnicas longevas para elaborar sua descrição: emprego de hipérboles e metáforas topográficas para amplificar o tamanho das ondas; invenção de um locus horrendus; uso da modéstia afetada para insistir na impossibilidade de se relatar o objeto testemunhado etc. Entretanto, também é possível notar que o autor seguiu de perto os preceitos associados ao sublime: ambientação sombria, transiçôes bruscas, ruídos incômodos, mobilização de elementos magníficos, desordenados e grandiosos etc. Por se tratar de uma descriçáa vívida, parece-nos que as técnicas antigas viriam a servir ao sublime. No entanto, Poe não recorreu a esse expediente para atender aos protocolos da tradição, aos preceitos das artes miméticas, mas para gerar efeitos preestabelecidos com eficácia, afetando o espírito do leitor, causando-lhe simpatia (no sentido que Burke atribuiu ao conceito) ou compaixão (segundo Schiller). A novidade, a originalidade tornou-se um objeto discursivo privilegiado na medida em que se mostrou capaz de alimentar a curiosidade e suscitar o deleite do leitor. Trata-se, poder-se-ia dizer, de uma nova tópica, de um argumento que buscou evidenciar uma "ruptura" pautada na liberdade do gênio criativo.

A distância, que Burke e Schiller consideraram algo necessário para a promoção do juízo estético, uma vez que o homem acometido por um infortúnio seria incapaz de sentir prazer, encontra-se subentendida nos contos de Poe. No entanto, seria inadequado imaginar que esse critério foi estabelecido na Modernidade. Basta recordar do que disse Aristóteles no livro I de sua Retórica ao retomar a seguinte passagem da Odisseia: "O homem, muito depois, experimenta o prazer mesmo ao preço/ De recordar os sofrimentos, se houver muito suportado e mourejado". Na sequência, ele afirma que o "prazerosamente memorável não é apenas o que, quando efetivamente presente, era prazeroso, mas também algumas coisas que não eram, desde que seus resultados posteriormente revelaram-se nobres e bons". É prazeroso, diz ele, "o simples estar livre do mal" (ARISTÓTELES, 2011, p. 94).

Entre os romanos cogitava-se que a narrativa de infortúnios poderia igualmente provocar deleite, caso tratasse de matéria alta, escrita com eloquência. É o caso de Cícero que, por meio de uma carta, pediu ao amigo e historiador Lucéio para escrever e celebrar seu consulado: "Nossas desventuras te fornecerão, na escrita, uma grande variedade, cheia de um certo 
prazer que pode veementemente reter os espíritos na leitura, graças ao escritor que tu és" (CÍCERO apud HARTOG, 2001, p. 157). O procedimento aludido por Cícero insistia no prazer decorrente das vicissitudes da Fortuna e tomava a escrita eloquente como necessária à efetivaçáo deste mesmo prazer. $\mathrm{O}$ autor romano tratou da pietas como sentimento agradável da mesma forma como a simpatia foi encarada por Burke, Kant e Adam Smith. A distância temporal apareceu como uma demanda conveniente que poderia atenuar a dor e amplificar o deleite. A ideia de sublime, trabalhada com esmero durante o Romantismo, dependeu desse critério. Chegou-se à conclusão de que a arte seria um instrumento apropriado capaz de conferir vivacidade a um mal, trazendo-o à presença do leitor/ouvinte subtraído de todo o perigo que incapacitaria o deleite estético.

Aristóteles definiu o medo ( $\phi$ óßos, phóbos) como uma "forma de padecimento ou perturbação gerada pela representação de um mal vindouro de caráter destrutivo ou penoso" (ARISTÓTELES, 2011, p. 137). Nós tememos, segundo o estagirita, "aquilo que pode nos causar profundos sofrimentos e grandes perdas, inclusive nossa destruição. E mesmo isso somente se parecerem não distantes, mas tão próximos a ponto de serem iminentes" (p. 138). Produz medo, portanto, "tudo que se afigura como detentor de um grande poder destrutivo e capacidade de causar danos que terão como consequências profundos sofrimentos" (p. 138). O perigo, no caso, seria a aproximação do que tememos, resultado de sinais capazes de trazer consigo um relance do perigo vindouro. Mas o que é temível? De acordo com Aristóteles, "tudo o que, acontecendo ou devendo acontecer aos nossos semelhantes, é passível de provocar compaixão" (p. 139). O medo apenas se manifesta quando há esperança, afinal, ele leva-nos a deliberar. Trata-se do contrário da confiança: ambos se baseiam na expectativa, mas um espera o melhor; o outro, o pior. Assim, "diante dos perigos do mar, alguns têm confiança no porvir porque não conhecem por experiência uma tormenta, outros porque a prática que adquiriram com a experiência lhes fornece os meios de enfrentar a tormenta" (p. 141). Desse modo, os seres humanos enfrentam o perigo sem medo quando nunca tiveram a experiência do perigo ou quando dispóem de meios para lidar com ela. O medo pode, também, ser despertado por meio do discurso: para tanto, seria necessário "transportá-los para um estado em que se creiam ameaçados por alguma coisa, destacando que isso ocorreu com outros que eram mais fortes do que eles, e que está ocorrendo ou ocorreu com pessoas como eles próprios, nas mãos de pessoas que não faziam parte de sua expectativa, de uma forma inesperada e em circunstâncias relativamente às quais pensavam estar protegidos" (p. 140).

A ideia de distância, referida por Burke e Schiller, assim como a concepção da simpatia, enquanto sentimento inato e universal, levaram às últimas consequências a reflexão de Aristóteles sobre o medo. Seguramente, o narrador do "Manuscrito" não se encontrava em condiçôes de apreender esteticamente a tempestade que o afligia: primeiro, porque já havia presenciado outras intempéries marítimas; além disso, a intensidade da procela náo lhe concedia meios de enfrentá-la. Estas, segundo o estagirita, seriam as únicas maneiras de se 
refrear o terror e esboçar uma reação. Poe, no caso, soube modelar o discurso para retratar uma experiência verossímil, talvez porque pretendesse despertar no leitor o medo ao ressaltar a imprevisibilidade de um fenômeno natural dessa envergadura. $O$ protagonista do conto, por outras palavras, não figurou o heroísmo épico, mas demonstrou a fragilidade de uma alma diante de experiências desprovidas de qualquer consolo.

\section{A retórica, a estética e a ciência}

Voltemos a uma das epígrafes do artigo: Poe afirmou que quem nunca enfrentou uma tempestade seria incapaz de imaginar eficazmente seus efeitos. Com descriçóes vívidas criadas para proporcionar um determinado efeito, o autor buscou confrontar sua própria máxima, ou seja, fazer com que o leitor pudesse presenciar uma tempestade sem precisar enfrentá-la empiricamente, para fruir esteticamente a experiência figurada. Buscou-se encantar, desconcertar, afetar o espírito com expressóes capazes de impactar o psicológico da audiência, proporcionando uma sensação singular. O que Schiller pretendia com a tragédia, Poe parece ter buscado por meio de seus contos e poemas, associando com frequência o sublime e o grotesco para, com essa associação, impactar seu leitor, dando-lhe a impressão de sua fragilidade sem, no entanto, ameaçar de fato sua existência.

Edgar Allan Poe recorreu a várias figuras de linguagem presentes em Homero, Virgílio, Camóes etc. sem, necessariamente, ter lido todos eles. Isso porque suas escolhas narrativas voltavam-se para o deleite de seus leitores, e não para uma subserviência à mímese aristotélica. ${ }^{3}$ Uma descrição vívida, portanto, seria capaz de desfilar na frente dos olhos de sua audiência cenas verdadeiramente trágicas, grotescas, sublimes. Ele recorreu à arte para apropriar-se de fenômenos naturais tendo em mente certos efeitos. Esta foi a tempestade que antecedeu os satélites ou quaisquer escalas de mediçáo: sua medida inicialmente era ditada pelo estilo e, depois, foi oferecida pela estética. Por outras palavras, esse lugar-comum foi mensurado pelos olhos "prescritivos" da tradiçáo e, em seguida, pelo olhar "expressivo" do Romantismo para, só então, cair nas mãos da ciência. Não se trata de uma hierarquia evolutiva amparada no progresso, mas de "regimes de visibilidade", ou melhor, de maneiras distintas de se encarar a natureza e sua (im)previsibilidade, elaborando questóes datadas capazes de suprir nossas carências epistemológicas, sejam elas retóricas, estéticas ou científicas.

Convém retomar uma pergunta que foi feita em outro momento: o que há de novidade quando se compara o conto de Poe e as descriçôes épicas da tempestade? Em termos formais, a diferença não é considerável. Talvez, o que deva ser levado em conta são as dife-

\footnotetext{
3 Talvez essa versatilidade tenha causado impressão em Baudelaire a ponto de levá-lo a afirmar como fato assinalável que "um homem de imaginação tão erradia e táo ambiciosa seja ao mesmo tempo tão amoroso das regras, e capaz de análises estudiosas e de pacientes pesquisas. Dir-se-ia uma antítese feita carne" (BAUDELAIRE, 2017, p. 26-27).
} 
renças no que diz respeito à circulação, consumo e recepção das práticas letradas. Virgílio, por exemplo, escreveu para servir à res publica encabeçada por Otávio Augusto; Camóes, para mostrar-se um bom súdito da Coroa portuguesa, um excelente seguidor dos preceitos católicos e alguém preocupado com o bem comum. No século XIX, com o aprimoramento da imprensa e com a invenção da mais-valia, adotou-se um sentido mais individual, com a consagração profissional se tornando um critério fundamental. A partir de entấo, buscou-se uma visão de mundo capaz de retratar a fragilidade da condição humana, desamparada pelo poder divino, figurando um homem abandonado à sua própria sorte. Evidentemente, poetas antigos e modernos não poderiam dedicar-se à arte sem o apoio de um mecenas, mas a questão não era somente sobreviver, mas também servir ao bem comum fazendo bons usos da pena para representar a ordem e defender o status quo.

Virgílio não poderia deixar de referir a pax romana como evidência de uma idade de ouro promovida por um princeps virtuoso, seguidor do mos maiorum; Camóes não poderia conceber a história como algo fora do providencialismo típico do Estado português, nem o poema épico sem as diretrizes e protocolos genéricos implicados em sua composiçáo. Se, no caso das epopeias analisadas, a descrição das intempéries podia ser lida como emulaçáo de lugares-comuns e como circunstância adequada para a manifestação de princípios virtuosos, no caso de Poe ela poderia muito bem ser considerada sintoma da psiquê ou das angústias de um homem empírico entretido com seus dilemas existenciais. Isso porque a noção de autor sofreu uma mudança substancial com a eliminação dos preceitos retóricos e com a construção romântica do narrador como homem que detém e divulga seu juízo estético. Edgar Allan Poe encontrava-se metido num mundo no qual os autores detinham os direitos autorais e integravam o mundo burguês, competindo para vender sua literatura. No caso da tradição épica, o autor era uma autoridade e, por meio de sua pena, elaborava um poema adequado à auctoritas do gênero praticado. Por isso, essa auctoritas não poderia ser concebida como realidade da psicologia individual de um homem, mas como dispositivo capaz de reciclar os preceitos do gênero supondo sua recepção. O leitor, dessa forma, lia os poemas como variaçôes de uma mesma tradição, apreendendo e julgando a qualidade da imitaçáo das auctoritates. Poder-se-ia falar de ressentimento e pessimismo por parte do autor americano, que vivia na pobreza e requisitava recorrentemente e de forma patética o apoio financeiro do pai adotivo por meio de cartas. No caso das epopeias, deparamo-nos com um conjunto de técnicas retóricas figuradas pela persona épica que, por meio da intempérie, representam paixóes mediadas por preceitos técnicos anônimos e, por isso, comuns. Em ambos os casos, a preocupação do auctor/autor volta-se para o páthos, inicialmente regrado e depois, expressivo e psicológico. 


\section{Referências}

ANCHIETA, José de. De Gestis Mendi de Saa. São Paulo: Edições Loyola, 1986.

ARÁTOR. História Apostólica - A gesta de São Paulo. Tradução do latim, introdução e notas de José Henrique Manso. Universidade de Coimbra: Centro de Estudos Clássicos e Humanísticos, 2010.

ARENDT, Hannah. A condição humana. Rio de Janeiro: Forense, 1981.

ARISTÓTELES. Retórica. São Paulo: EDIPRO, 2011.

BAUDELAIRE, Charles. O homem e a obra (1852). In: POE, Edgar Allan. Edgar Allan Poe: medo clássico: coletânea inédita de contos do autor. Rio de Janeiro: DarkSide Books, 2017.

BURKE, Edmund. Uma investigação filosófica sobre a origem de nossas ideias do sublime e do belo. Campinas, SP: Editora da Universidade de Campinas, 1993.

CAMÓES, Luís de. Os lusiadas. Porto Alegre: L\&PM, 2008.

HARTOG, François. A história de Homero a Santo Agostinho. Belo Horizonte: Ed. UFMG, 2001.

HOMERO. Ilíada. São Paulo: Penguin Classics Companhia das Letras, 2013.

HOMERO. Odisseia. São Paulo: Penguin Classics Companhia das Letras, 2011.

HUGO, Victor. Do grotesco e do sublime. São Paulo: Perspectiva, 2014.

KANT, Immanuel. Observaçóes sobre o sentimento do belo e do sublime. Seguido de "Ensaio sobre as doenças da cabeça". Lisboa: Ediçôes 70, 2012.

LOHNER, José Eduardo dos Santos. Nota introdutória. In: SÊNECA. Agamêmnon. São Paulo: Globo, 2009.

MANSO, José Henrique. Introdução. In: ARÁTOR. História Apostólica - A gesta de São Paulo. Universidade de Coimbra: Centro de Estudos Clássicos e Humanísticos, 2010.

POE, Edgar Allan. Edgar Allan Poe: medo clássico: coletânea inédita de contos do autor. Rio de Janeiro: DarkSide Books, 2017.

POE, Edgar Allan. Edgar Allan Poe: medo clássico: v. 2. Rio de Janeiro: DarkSide, 2018.

SCHILLER, Fredrich. Do sublime. In: SÜSSEKIND, Pedro (org.). Fredrich Schiller: do sublime ao trágico. Belo Horizonte: Autêntica, 2011.

SCHILLER, Fredrich. Sobre o sublime. In: SÜSSEKIND, Pedro (org.). Fredrich Schiller: do sublime ao trágico. Belo Horizonte: Autêntica, 2011.

TORRÃO, João. Manuel Nunes. A tempestade no De Gestis Mendi de Saa. In: Actas do Congresso Internacional. Porto: Edição da Fundação Eng. António de Almeida, 2000.

VIRGÍliO. Eneida de Virgílio. São Paulo: Martins Fontes, 2004. 